\title{
Accumulation of a nod Gene Inducer, the Flavonoid Naringenin, in the Cytoplasmic Membrane of Rhizobium leguminosarum biovar viciae Is Caused by the $\mathrm{pH}-$ Dependent Hydrophobicity of Naringenin
}

\author{
KEES RECOURT, ${ }^{1 *}$ ANTON A. N. VAN BRUSSEL,${ }^{1}$ ARNOLD J. M. DRIESSEN,$^{2}$ AND BEN J. J. LUGTENBERG ${ }^{1}$ \\ Department of Plant Molecular Biology, Leiden University, Nonnensteeg 3, $2311 \mathrm{VJ}$ Leiden, ${ }^{1}$ and Department of \\ Microbiology, University of Groningen, Kerklaan 30, 975I NN Haren, ${ }^{2}$ The Netherlands
}

Received 22 November 1988/Accepted 10 May 1989

\begin{abstract}
Most Sym plasmid-localized nodulation genes of Rhizobium leguminosarum bv. viciae are only expressed upon activation of the NodD protein by plant flavonoids, e.g., naringenin (S. A. J. Zaat, C. A. Wijffelman, H. P. Spaink, A. A. N. van Brussel, and B. J. J. Lugtenberg, J. Bacteriol. 169:198-204, 1987). As part of a study on the mechanism of NodD protein activation, the mechanism of uptake and the intracellular fate of $\left[{ }^{3} \mathrm{H}\right]$ naringenin were studied. Naringenin was accumulated by Rhizobium cells without apparent metabolic conversion to an $\mathbf{8 0}$-fold-higher concentration in a process which did not require any of the other Sym plasmid-localized nod genes. Naringenin accumulation was nonsaturable, highly reversible, and not inhibited by the presence of other flavonoids or the metabolic inhibitors potassium cyanide, sodium azide, 2,4dinitrophenol, and carbonyl cyanide $m$-chlorophenylhydrazone. These data indicate an accumulation mechanism without high affinity sites which does not use cellular energy. In vitro, naringenin has high affinity for the cytoplasmic membrane. This binding was pH dependent, very high at pH 5.7 and not present anymore at pH 9.7. A similar pH dependency was found for the affinity of naringenin for the olive oil fraction of a biphasic olive oil-water system. pH-dependent changes in the UV spectrum indicate ionization of naringenin at high $\mathrm{pH}$ to a negatively charged form. Since it has recently been shown that the nodD gene product is located in the cytoplasmic membrane (H. R. M. Schlaman, H. P. Spaink, R. J. H. Okker, and B. J. J. Lugtenberg, J. Bacteriol., in press), our data are consistent with a model in which the un-ionized form of naringenin accumulates in the cytoplasmic membrane and activates, in a metabolically unaltered form, the NodD protein.
\end{abstract}

Bacteria of the genus Rhizobium interact with leguminous plants in a host-specific manner and form nitrogen-fixing root nodules. In an early stage of this symbiosis, free-living bacteria attach to root hair tips, induce marked root hair curling and other visible alterations of the root morphology, and subsequently enter the host plant via infection threads in the root hairs $(21,23-25)$. The bacterial nod (for nodulation) genes required in this early stage are located on a large so-called Sym (for symbiosis) plasmid and code for "common" and host-specific nodulation functions (13). Transcription of the nod genes is mediated by the nodD regulatory gene product upon activation by flavonoids exuded by the plant roots $(5,11,14,19,20,26,27)$.

The host specificity of the symbiosis is partly determined by the source of the nodD gene and the sets of inducers present in the root exudate $(22,28)$. In contrast to strains of Rhizobium leguminosarum bv. viciae and $R$. leguminosarum bv. trifolii, Rhizobium meliloti contains three functional copies of nodD, each of which may play different regulatory roles in the establishment of host-specific symbiosis (9). Evidence has been provided that the nodD product binds to the nodA promotor. This binding is independent of the presence of inducing flavonoids $(6,8)$.

Studies on induction profiles of wild-type NodD proteins, and with nodD mutants and hybrids of different nodD genes which display an altered flavonoid specificity, suggest a

\footnotetext{
* Corresponding author.
}

direct interaction of the inducer with the product of $\operatorname{nodD}(3$, $11,22)$. Since flavonoids induce the nod genes at very low (nanomolar) concentrations, one can calculate that at the minimal inducing concentration of $2.5 \mathrm{nM}(27)$, in the absence of an accumulation mechanism, only one molecule of naringenin is present in a Rhizobium cell, which has a volume of $0.6 \times 10^{-13} \mathrm{ml}$. Thus, a mechanism must exist to accumulate flavonoids in the bacterial cell in order to allow their interaction with the nodD gene product.

As a first attempt to unravel the mechanism of inducible nod gene transcription, we investigated the accumulation of the nod gene activator naringenin by $R$. leguminosarum bv. viciae (27). The results indicate that the accumulation of naringenin is independent of the presence of or activation of nodulation genes, and data are provided which suggest that naringenin accumulates rapidly in the cytoplasmic membrane.

\section{MATERIALS AND METHODS}

Bacterial strains, plasmids, and growth conditions. $R$. trifolii LPR5045, cured of its Sym plasmid pRtr5a (10), and strain RBL5560, an LPR5045 derivative containing the $R$. leguminosarum Sym plasmid pJB5JI (27), were used for uptake experiments. The plasmid pMP154 contains the nodA promoter of $R$. leguminosarum bv. viciae plasmid pRL1JI fused to the Escherichia coli structural gene lacZ (27). Bacteria were maintained at $28^{\circ} \mathrm{C}$ on solid YMB medium, which contains yeast extract and mannitol (10). They were grown routinely in induction medium $(\mathrm{pH} \mathrm{6)}$, which is 
composed of $10 \%$ mannitol-nitrate medium supplemented with deposit-free Jensen medium and potassium phosphate buffer, final concentration $10 \mathrm{mM}$ (27), to an $A_{660}$ of 0.2 (5 $\times$ $\left.10^{8} \mathrm{CFU} / \mathrm{ml}\right)$ on a rotary shaker $(200 \mathrm{rpm})$ at $28^{\circ} \mathrm{C}$.

Assay for initiation of transcription of promotor of nodA gene of plasmid pRL1JI. Strain RBL5560(pMP154), which harbors plasmid pMP154, was used to assay the nod geneinducing activity of naringenin as described previously (27). The cells were grown and tested in induction medium at different $\mathrm{pH}$ values by adjusting the $\mathrm{pH}$ of the phosphate buffer.

Assay of $\left[{ }^{3} \mathbf{H}\right]$ naringenin uptake. Cells grown to an $A_{660}$ of 0.2 in induction medium were harvested by centrifugation and suspended to an $A_{660}$ of 0.2 in uptake medium, which consists of $10 \%$ mannitol-nitrate medium supplemented with $5 \mathrm{mM} \mathrm{CaCl}_{2}, 5 \mathrm{mM} \mathrm{MgCl}$, and $10 \mathrm{mM}$ potassium phosphate, $\mathrm{pH}$ 6. After incubation for $30 \mathrm{~min}$ at $28^{\circ} \mathrm{C}$ in a water bath under continuous stirring, uptake was started by the addition of a small portion of $\left[{ }^{3} \mathrm{H}\right]$ naringenin from a $620 \mu \mathrm{M}(120$ $\mathrm{GBq} / \mathrm{mmol}$ ) stock solution in ethanol to a final concentration of between 10 and $600 \mathrm{nM}$. At various time intervals, duplicate samples of the cell suspension were assayed for naringenin uptake by using either membrane filters or silicone oil centrifugation to separate free and cell-bound radioactivity. Initially, membrane filters (Millipore HVLP 2500, Sartorius cellulose nitrate SM113 or cellulose acetate SM 111 , Gelman polysulfone HT 200, or Schleicher \& Schull ME 24, BA 83, and NL 16) were used to trap the bacteria. However, much better results were obtained when cells were separated from the incubation medium by centrifugation through silicone oil by the slightly modified method of Kashket (12). Samples $(0.5 \mathrm{ml})$ were layered on top of a 0.3-ml silicone oil mixture consisting of $70 \%$ ( $\mathrm{vol} / \mathrm{vol})$ AR20 and 30\% (vol/vol) AR200 (Wacker Chemie, Munich, Federal Republic of Germany).

After centrifugation for $3 \mathrm{~min}$ in an Eppendorf centrifuge (type 5414S), the tubes were turned upside down and the tip containing the cell pellet was cut with a wire cutter so that it fell directly into a scintillation vial. After suspension of the cell pellet in $1.0 \mathrm{ml}$ of distilled water, $8.0 \mathrm{ml}$ of scintillation liquid (Quickzint 212; Zinsser Analytic, Maidenhead, Berkshire, England) was added, and the radioactivity was determined with a LKB-1214 Rackbeta scintillation counter (LKB, Turku, Finland). Internal cell volume was determined with ${ }^{3} \mathrm{H}_{2} \mathrm{O}$ as described by Kashket (12) after correction was made for the medium trapped in the cell pellets by using $\left[{ }^{14} \mathrm{C}\right]$ dextran as the nonpermeable molecule. For cells of strains LPR5045 and LPR5560, the extracellular volume was found to be approximately $250 \%$ of the intracellular volume of $7 \mu \mathrm{l} / \mathrm{mg}$ of cellular protein. The extracellular volume contained $0.2 \%$ of the input radioactivity.

To determine the effect of the $\mathrm{pH}$ on naringenin uptake, cells were harvested, washed, and suspended in uptake medium buffered with $20 \mathrm{mM}$ MES (2- $N$-morpholinoethanesulfonic acid) (pH 5.5 to 6.0), $20 \mathrm{mM}$ MOPS (3- $N$-morpholinopropanesulfonic acid) ( $\mathrm{pH} 6.5$ to 7.0$), 20 \mathrm{mM}$ Tris (pH 7.5 to 9.0 ), or $20 \mathrm{mM}$ glycine (pH 9.5 to 10.5 ) to an $A_{660}$ of 0.2 and incubated for $15 \mathrm{~min}$ at $28^{\circ} \mathrm{C}$ with $200 \mathrm{nM}\left[{ }^{3} \mathrm{H}\right.$ ]naringenin $(120 \mathrm{GBq} / \mathrm{mmol})$. Duplicate samples were taken, centrifuged through silicone oil as described above, and analyzed for radioactivity. Uptake was expressed as picomoles of cellbound naringenin per milligram of cellular protein.

Experiments with metabolic inhibitors. Potassium cyanide $(10 \mathrm{mM})$, sodium azide $(10 \mathrm{mM}), 2,4$-dinitrophenol (DNP; $0.05 \mathrm{mM}$ ), and carbonyl cyanide $m$-chlorophenylhydrazone (CCCP; $0.01 \mathrm{mM}$ ) were added to the bacterial suspensions 15 min prior to the addition of naringenin at the indicated final concentrations.

TLC. Cells grown to an $A_{660}$ of 0.2 were incubated at $28^{\circ} \mathrm{C}$ with $\left[{ }^{3} \mathrm{H}\right]$ naringenin $(120 \mathrm{GBq} / \mathrm{mmol})$ at a final concentration of $150 \mathrm{nM}$. At various time intervals, cells were centrifuged through silicone oil, and cell pellets with an internal volume of $0.6 \mathrm{ul}$ were suspended in $1.0 \mathrm{ml}$ of $\mathrm{H}_{2} \mathrm{O}$, which resulted in an efflux of approx. $95 \%$ of the accumulated radioactivity. After centrifugation of the cells, the supernatant fluid was extracted with $1.0 \mathrm{ml}$ of $100 \%$ ethyl acetate, and samples of the aqueous and ethyl acetate phases were assayed for radioactivity. Essentially all radioactivity was recovered in the ethyl acetate fraction. The extracted radioactivity was concentrated by evaporation at $20^{\circ} \mathrm{C}$ to $0.1 \mathrm{ml}$. For thin-layer chromatography (TLC), $20 \mu$ l of the extract was applied to a cellulose plate (type 5574; Merck, Darmstadt, Federal Republic of Germany) and eluted with chloroform-acetic acidwater $(10: 9: 1 ; \mathrm{vol} / \mathrm{vol} / \mathrm{vol})$ as the solvent. Original $\left[{ }^{3} \mathrm{H}\right]$ naringenin was used as a standard. Unlabeled flavonoids were eluted as controls and were detected under UV light at a wavelength of $366 \mathrm{~nm}$. After drying, radioactivity was determined in $0.05-R_{f}$ segments.

UV spectrometry. Continuous spectra were recorded with a Pye Unicam spectrophotometer (type sp-100; Pye, Cambridge, England) in quartz cuvettes with an optical pathway of $1 \mathrm{~cm}$.

Partitioning of naringenin between water and olive oil. The relative hydrophobicity of naringenin was determined by using olive oil as the hydrophobic phase $(2) .\left[{ }^{3} \mathrm{H}\right]$ naringenin $(120 \mathrm{GBq} / \mathrm{mmol})$ at a final concentration of $100 \mathrm{nM}$ was added to a biphasic solution of olive oil and distilled water buffered with $20 \mathrm{mM}$ MES (pH 5.5 to 6.0 ), $20 \mathrm{mM}$ MOPS (pH 6.5 to 7.0), $20 \mathrm{mM}$ Tris (pH 7.5 to 9.0 ), or $20 \mathrm{mM}$ glycine (pH 9.5 to 10.5). After vigorous mixing, the phases were separated by centrifugation, and $50-\mu l$ samples were collected from each phase. The amount of radioactivity was determined by scintillation counting.

Separation of cytoplasmic and outer membranes. Total membranes were isolated after cell disruption with a French pressure cell as described previously (4) with the following slight modifications. After harvesting, approximately $2 \times 10^{9}$ cells were sheared for $10 \mathrm{~min}$ at half maximum speed in an Omnimixer (Sorvall Inc., Newtown, Conn.) to remove capsular material. This treatment improved the quality of the subsequent membrane separation. $\left[{ }^{3} \mathrm{H}\right]$ naringenin $(75 \mathrm{pmol}$, $120 \mathrm{GBq} / \mathrm{mmol}$ ) was added to a suspension of total membranes in $0.5 \mathrm{ml}$ of $15 \%$ sucrose, and the suspension was layered on top of a discontinuous sucrose gradient consisting of $1.5 \mathrm{ml}$ of $60 \%, 4 \mathrm{ml}$ of $40 \%$, and $4.5 \mathrm{ml}$ of $25 \%$ (wt/wt) sucrose in $5 \mathrm{mM}$ EDTA. All solutions used in the sucrose density centrifugation were buffered with $50 \mathrm{mM}$ MES ( $\mathrm{pH}$ 5.7), $50 \mathrm{mM}$ MOPS (pH 7.0), $50 \mathrm{mM}$ Tris (pH 8.0), or $50 \mathrm{mM}$ glycine $(\mathrm{pH} 9.7)$. The tubes were centrifuged for $12 \mathrm{~h}$ at $58,000 \times g$ in a Kontron rotor (type TST 28.38; Kontron Instruments Inc., Zurich, Switzerland), which resulted in a banding pattern similar to that described previously (4) except that the very minor sharp intermediary band migrated very close to the heavy outer membrane band. Fractions $(0.3$ $\mathrm{ml})$ were collected, and the amount of radioactivity was determined. Protein was assayed by the method of Lowry et al. (16) with bovine serum albumin as a standard. NADH oxidase activity and 2-keto-3-deoxyoctonate content were estimated as described previously (4).

Radiochemicals and other chemicals. $\left[{ }^{3} \mathrm{H}\right] \mathrm{Naringenin}$ was obtained from the Radiochemical Center (Amersham, United Kingdom) and was labeled by the catalytic-exchange 
method with glacial acetic acid and ${ }^{3} \mathrm{H}_{2} \mathrm{O}$, resulting in a specific activity of $120 \mathrm{GBq} / \mathrm{mmol}$. With this method, the following distribution of the radioactivity is obtained: $90 \%$ at the $6,8,2^{\prime}$, and $4^{\prime}$ positions, and $10 \%$ at the 3 position of naringenin. No radioactivity is present at the hydroxyl groups. Tritium exchange in aqueous solutions appeared to be inversely correlated with the $\mathrm{pH}$. By TLC analysis, at $\mathrm{pH}$ $5.010 \%$ of the tritium label was exchanged after $30 \mathrm{~min}$ of incubation. At $\mathrm{pH}$ 6.0, approx. $10 \%$ of the tritium was exchanged after $8 \mathrm{~h}$ of incubation. At pHs of 7.0 or higher, significant tritium exchange could not be detected after $24 \mathrm{~h}$ of incubation. In organic solutions (methanol, ethanol), no significant tritium exchange could be detected. $\left[{ }^{14} \mathrm{C}\right]$ Dextran (44.4 MBq/g) and ${ }^{3} \mathrm{H}_{2} \mathrm{O}(1.66 \mathrm{GBq} / \mathrm{mol})$ were obtained from New England Nuclear Corp. (Boston, Mass.). All unlabeled chemicals were of analytical grade and obtained from commercial sources.

\section{RESULTS}

Evaluation of two methods for measuring naringenin uptake. In the absence of cells, membrane filters retained 5 to $85 \%$ of the input radioactive naringenin. The amount of filter-bound radioactivity was strongly dependent on the sample volume, the filtration rate, and the filter type. Preincubation of the filter with unlabeled naringenin did not saturate binding. Adequate measurements of naringenin accumulation in the bacteria retained on the filter were impossible due to the high and variable background of the filter. Separation of free and cell-bound radioactivity by centrifugation through silicone oil yielded reproducible results. Duplicate samples varied less than $3 \%$, and only approximately $0.2 \%$ of the input radioactivity was trapped in the extracellular volume of the cell pellet at a bacterial concentration of $5 \times 10^{8} \mathrm{CFU} / \mathrm{ml}$. Therefore, the latter method was used in all subsequent experiments.

Characteristics of naringenin uptake by $R$. leguminosarum bv. viciae at pH 6. The amount of naringenin bound by cells of strain RBL5560, which harbors the Sym plasmid pRL1JI, was independent of the incubation time (Fig. 1). With a cellular volume of $7 \mu \mathrm{l} / \mathrm{mg}$ of cellular protein, the concentration of cell-bound radioactivity was calculated to be approximately 80 -fold higher than the medium concentration, and this accumulation ratio was constant up to at least $600 \mathrm{nM}$ naringenin (Fig. 1, inset). At $100 \mathrm{nM}$ naringenin, which causes maximal nod gene activation (27), approximately 3,500 molecules of naringenin were calculated to be associated with one bacterium.

In order to determine whether activation of nod genes affected the accumulation ratio, RBL5560 cells were grown for $24 \mathrm{~h}$ with $100 \mathrm{nM}$ unlabeled naringenin and subsequently incubated in $70 \mathrm{nM}\left[{ }^{3} \mathrm{H}\right]$ naringenin. The results showed an accumulation ratio indistinguishable from that for noninduced cells and were even the same as for strain LPR5045, which does not harbor any Sym plasmid. In order to investigate the presence of a high-affinity transport system, with a $K_{m}$ equal to or smaller than the half-maximal concentration for nod gene induction, which is $15 \mathrm{nM} \mathrm{(27),} \mathrm{unlabeled}$ naringenin was added shortly prior to or during incubation with radioactive naringenin. No inhibition of accumulation or reduction of the amount of $\left[{ }^{3} \mathrm{H}\right]$ naringenin accumulated was found in the presence of unlabeled naringenin up to a final concentration of $1 \mu \mathrm{M}$. The same results were found when eriodictyol, apigenin, luteolin, or hesperetin, all of which activate the tested nodA promoter, was added instead of naringenin (28). Independent of the incubation period, the

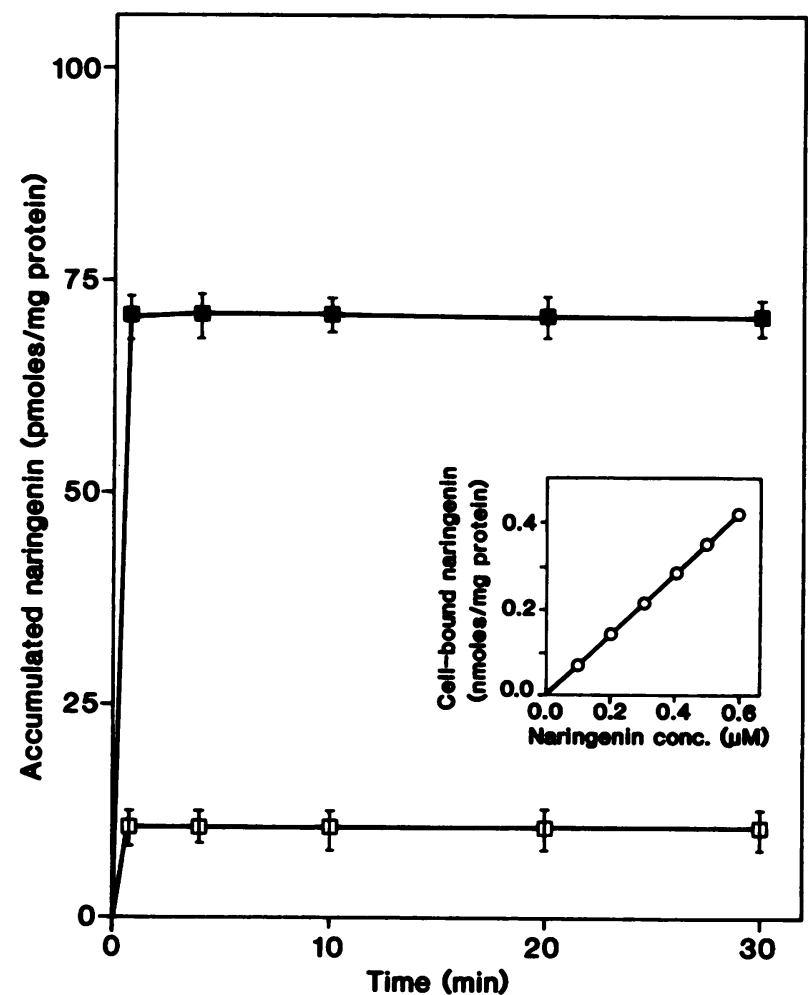

FIG. 1. Time course of uptake of $\left[{ }^{3} \mathrm{H}\right]$ naringenin by cells of $R$. leguminosarum bv. viciae RBL5560. Cells were incubated with final naringenin concentrations of $15(\square)$ and $100(\square) \mathrm{nM}$. Duplicate samples were taken at various time intervals as described in the text. Inset: Amount of cell-bound naringenin as a function of the naringenin concentration. Values represent averages of five samples.

accumulation of naringenin appeared to be highly reversible, since resuspension of cells which had been incubated with $150 \mathrm{nM}\left[{ }^{3} \mathrm{H}\right]$ naringenin into uptake medium without naringenin resulted in a rapid efflux of ca. $95 \%$ of the accumulated radioactivity (Fig. 2 ).

Analysis of the effluxed radioactivity with a one-dimensional TLC system, which can differentiate between various flavonoids (28), did not indicate any metabolic conversion, since the chromatographic mobility of $\left[{ }^{3} \mathrm{H}\right]$ naringenin was indistinguishable from that of nonincubated $\left[{ }^{3} \mathrm{H}\right]$ naringenin (Fig. 2, inset).

Effect of metabolic inhibitors and temperature on naringenin accumulation at pH 6. Potassium cyanide, sodium azide, DNP, and CCCP were used to investigate whether accumulation of naringenin is energy dependent. Addition of these dissipators of the proton motive force resulted in an instantaneous increase of naringenin accumulation to a new steady-state level (Table 1). The accumulation of naringenin was four times higher at $4^{\circ} \mathrm{C}$ than at $28^{\circ} \mathrm{C}$ under these conditions. However, addition of metabolic inhibitors or incubation at $4^{\circ} \mathrm{C}$ abolished nod gene expression completely, as shown by the lack of induction of the nodAp-lacZ transcription vector (27) by naringenin. Most likely these conditions prevent protein synthesis which is necessary for detection of nod gene activation.

Effect of pH on naringenin accumulation. The amount of cell-bound naringenin was strongly dependent on the $\mathrm{pH}$ of the incubation medium. With increasing $\mathrm{pH}$, the quantity of cell-associated naringenin decreased drastically, and at $\mathrm{pH}$ 


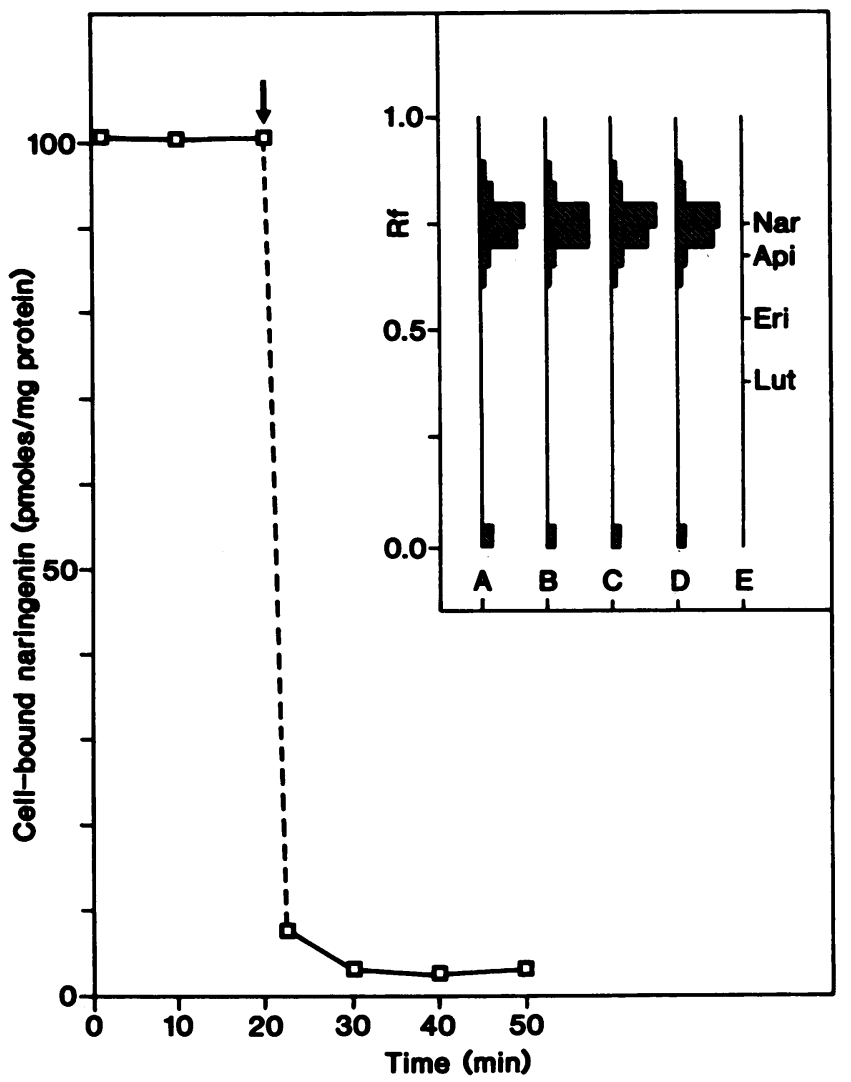

FIG. 2. Time course of the efflux of $\left[{ }^{3} \mathrm{H}\right]$ naringenin by $R$. leguminosarum bv. viciae RBL5560 cells. After incubation in the presence of $150 \mathrm{nM}\left[{ }^{3} \mathrm{H}\right]$ naringenin, cells were centrifuged and resuspended in the same volume of uptake medium without naringenin (arrow). Subsequently, the amount of cell-bound radioactivity was determined. Inset: TLC of ethyl acetate extracts of supernatant fluids of cells obtained after incubation for various periods with $\mathbf{1 5 0}$ $\mathrm{nM}\left[{ }^{3} \mathrm{H}\right]$ naringenin, centrifugation through silicone oil, and subsequent suspension in $\mathrm{H}_{2} \mathrm{O}$. Dotted areas represent ca. $10 \mathrm{kdpm} / 0.05$ $\boldsymbol{R}_{\boldsymbol{f}}$ segment. Symbols: A, standard $\left[{ }^{3} \mathrm{H}\right]$ naringenin; B, C, and D. analysis of radioactivity after incubation of cells with $\left[{ }^{3} \mathrm{H}\right]$ naringenin for 5, 120, and $240 \mathrm{~min}$, respectively; E, $R_{f}$ values of the nonlabeled reference compounds naringenin (Nar), apigenin (Api), eriodictyol (Eri), and luteolin (Lut).

10.5 it equalled the background level (Fig. 3). A similar $\mathrm{pH}$ dependence was found for the hydrophobic properties of naringenin. The affinity of flavonoids for olive oil has been shown to be a reliable standard for their relative hydrophobicity (2). Partitioning of naringenin between an aqueous and hydrophobic olive oil phase revealed that at $\mathrm{pH} 5.5$, approx-

TABLE 1. Effect of metabolic inhibitors and uncouplers on the accumulation of $\left[{ }^{3} \mathrm{H}\right]$ naringenin by cells of Rhizobium leguminosarum bv. viciae RBL5560

\begin{tabular}{lcc}
\hline Compound tested & $\begin{array}{c}\text { Final concn } \\
(\mathrm{mM})\end{array}$ & $\begin{array}{c}\text { Accumulation } \\
\text { (\% of control value)" }\end{array}$ \\
\hline None (control) & & 100 \\
Potassium cyanide & 10 & 160 \\
Sodium azide & 10 & 220 \\
DNP & 0.05 & 200 \\
CCCP & 0.01 & 250 \\
\hline
\end{tabular}

"Percentage of cell-bound naringenin was calculated 15 min after addition of $70 \mathrm{nM}\left[{ }^{3} \mathrm{H}\right]$ naringenin.

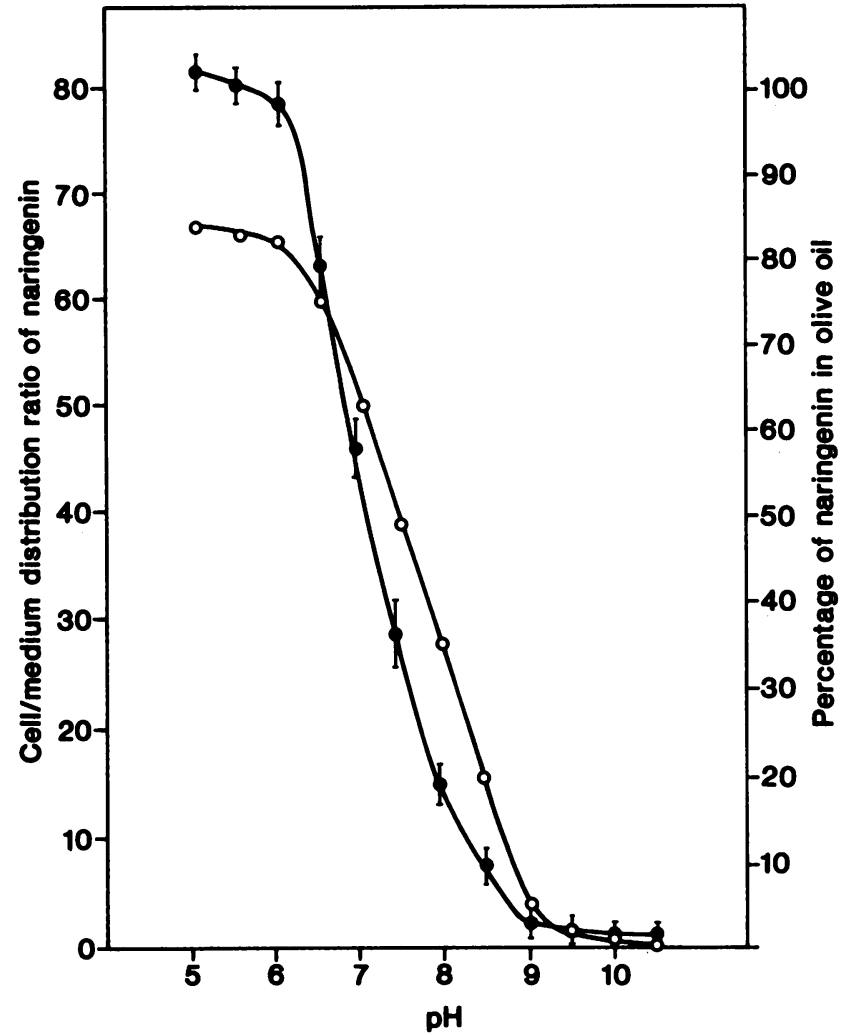

FIG. 3. Effect of $\mathrm{pH}$ on the accumulation of $\left[{ }^{3} \mathrm{H}\right]$ naringenin by cells $(\Theta)$ and on partitioning of naringenin between a hydrophilic and hydrophobic phase $(O)$. Strain RBL5560 grown in induction medium ( $\mathrm{pH}$ 6.0) was suspended in uptake medium of the appropriate $\mathrm{pH}$ to an $A_{660}$ of 0.2 . After incubation for $10 \mathrm{~min}$ with $\left[{ }^{3} \mathrm{H}\right]$ naringenin at a final concentration of $200 \mathrm{nM}$, duplicate samples were analyzed. Accumulation represents the ratio of the concentration of naringenin in the cells over that in the medium. Values represent averages of three measurements. To measure the effect of the $\mathrm{pH}$ on the partitioning coefficient of naringenin between olive oil and the aqueous phase $(\mathrm{O}),\left[{ }^{3} \mathrm{H}\right]$ naringenin at a final concentration of 100 $\mathrm{nM}$ was added to a biphasic solution of olive oil and $20 \mathrm{mM}$ aqueous buffer of the appropriate $\mathrm{pH}$ and vigorously mixed. After separation of the phases, samples of each phase were analyzed for radioactivity. Values represent averages of three experiments.

imately $85 \%$ of the radioactivity was present in the olive oil phase (Fig. 3). With increasing $\mathrm{pH}$, this percentage decreased, and at $\mathrm{pH} 10.5$ no radioactivity was detectable in the olive oil phase (Fig. 3). The apparent pKs for the $\mathrm{pH}$-dependent partitioning of naringenin in the cell-medium and olive oil-water phases were 7.0 and 7.7 , respectively (Fig. 3).

The $\mathrm{pH}$-dependent hydrophobicity of naringenin paralleled alterations in its UV spectrum (Fig. 4). The spectrum at pH 5.5 showed a single absorption maximum at a wavelength of $289 \mathrm{~nm}$, which varied inversely with a peak at $320 \mathrm{~nm}$ at $\mathrm{pH}$ 10.5. These data on partitioning and absorption maxima suggest the $\mathrm{pH}$-dependent existence of at least two forms of naringenin which have different hydrophobic properties.

Selective binding of naringenin to the cytoplasmic membrane. The partitioning experiments indicate that at $\mathrm{pH} 5.5$, naringenin is relatively hydrophobic. Since hydrophobic flavonoids exhibit a strong affinity towards biological or model membranes (7), the affinity of naringenin for the membranes of Rhizobium leguminosarum bv. viciae was investigated. 


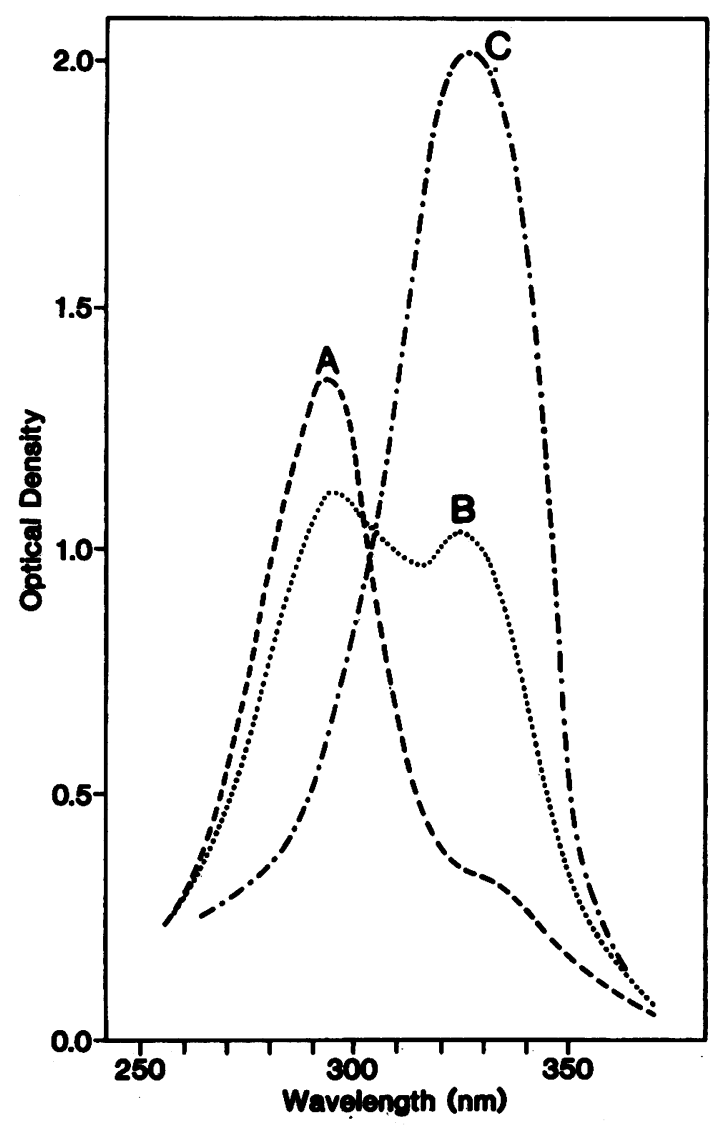

FIG. 4. Effect of $\mathrm{pH}$ on the UV absorption spectrum of naringenin. Spectra were recorded for $0.1 \mathrm{mM}$ aqueous solutions of naringenin in (A) $20 \mathrm{mM}$ MES (pH 5.5), (B) $20 \mathrm{mM}$ MOPS (pH 6.8), and (C) $20 \mathrm{mM}$ glycine (pH 10.0). Absorption peaks were found at 289 and $320 \mathrm{~nm}$.

$\left[{ }^{3} \mathrm{H}\right]$ naringenin was added to the total membrane fraction of strain RBL5560 at pH 5.7, 7.0, 8.0, and 9.7, and cytoplasmic and outer membranes were subsequently separated by sucrose gradient centrifugation. The two bands observed after centrifugation coincided with the $A_{280}$ absorption profiles (Fig. 5). The lower band (fractions 4 to 8 ) contained more than $90 \%$ of the 2-keto-3-deoxyoctonate content. The upper band contained approximately $90 \%$ of the NADH oxidase activity. With these results and the sodium dodecyl sulfate-polyacrylamide gel electrophoresis protein patterns of the fractions, which resembled the patterns shown for $\boldsymbol{R}$. leguminosarum 248 (4), the lower and upper bands were identified as the outer and cytoplasmic membranes, respectively. At the pHs studied, no radioactivity could be recovered from the outer membrane fractions (Fig. 5). At a pH of 5.7 , at which naringenin is soluble in olive oil, radioactivity accumulated in the cytoplasmic membrane fractions (Fig. 5).

The amount of naringenin bound to the cytoplasmic membrane decreased approximately $15 \%$ during the $12 \mathrm{~h}$ of incubation due to tritium exchange with the aqueous environment (see Materials and Methods, subsection Radiochemicals). At pH 7.0 and 8.0, accumulation of naringenin in the cytoplasmic membrane decreased (not shown), and at pH 9.7 radioactivity was only detectable in the upper fractions of the tube (Fig. 5). Since at those pHs significant tritium exchange could not be detected, the olive oil-insol- uble form of naringenin appears to have no affinity for the cytoplasmic membrane.

Correlation between pH and nod gene activation. To examine whether the decreasing affinity of naringenin for bacteria at increasing pHs affected nod gene activation, the $\beta$ galactosidase production of strain RBL5560(pMP154), which harbors the naringenin-inducible nodAp-lac $Z$ transcription fusion vector (27), was measured. Below pH 5.75 and above $\mathrm{pH} 7.0$, growth of cells decreased dramatically (not shown), and therefore only the $\mathrm{pH}$ range from 5.75 to 7.0 was investigated. At a naringenin concentration of $20 \mathrm{nM}$, at which nod genes are suboptimally activated (27), increasing the $\mathrm{pH}$ from 6.0 to 6.75 caused an approximately $35 \%$ reduction in $\beta$-galactosidase production (Table 2 ). No reduction occurred at $500 \mathrm{nM}$ naringenin, a concentration approximately fivefold higher than required for maximal nod gene expression (27). Below pH 6.0, $\beta$-galactosidase production decreased significantly independent of the naringenin concentration.

\section{DISCUSSION}

Accumulation of naringenin in Rhizobium spp. Since a naringenin concentration of $2.5 \mathrm{nM}$, which without accumulation corresponds to 1 molecule of naringenin per cell, is sufficient to induce nod gene expression (27), we expected that this compound and other inducing flavonoids would be accumulated by Rhizobium cells. Indeed it appeared that, assuming an even distribution of naringenin throughout the cell, the cellular concentration of naringenin is $\mathbf{8 0}$-fold higher than the extracellular concentration (Fig. 1). This corresponds to 3,500 molecules per cell at $100 \mathrm{nM}$ extracellular naringenin, a concentration which is sufficient for maximal induction. TLC of accumulated naringenin showed no evidence for intracellular metabolism (Fig. 2, inset), suggesting that naringenin itself is the compound which activates NodD protein. Interestingly, our data also show that the inducible nod genes are not required for accumulation of naringenin by Rhizobium cells.

Accumulation of naringenin does not require cellular energy. Accumulation of naringenin is characterized by a number of properties. (i) It is nonsaturable at concentrations up to at least $600 \mathrm{nM}$ (Fig. 1, inset). (ii) It is independent of the incubation time (Fig. 1). (iii) Addition of up to $1 \mu \mathrm{M}$ unlabeled activators, including naringenin, at least some of which can be expected to use the same accumulation mechanism as naringenin, did not reduce the uptake level of $\left[{ }^{3} \mathrm{H}\right]$ naringenin. (iv) When, after accumulation of inducer, cells were transferred to the same medium without naringenin, at least $95 \%$ of accumulated radioactivity effluxed (Fig. 2) and was indistinguishable from original naringenin. Since the volume of the bacterial fraction is approx. $0.6 \mu \mathrm{l} / \mathrm{ml}$ of medium, it can be calculated that a new 80:1 naringenin cell-to-medium distribution ratio is established. (v) Adding metabolic inhibitors to the suspension (Table 1) or decreasing the temperature to $4^{\circ} \mathrm{C}$ resulted in a substantial increase in accumulation. These data suggest that no specific highaffinity sites or uptake mechanism for naringenin is present. Instead, the presence of a proton motive force appears to reduce the accumulation of naringenin.

Intracellular accumulation and localization of naringenin. At a $\mathrm{pH}$ of 5.7, naringenin has a strong affinity for the cytoplasmic membrane but; surprisingly, not for the outer memibrane (Fig. 5). Since the accumulation of naringenin in whole cells is highly reversible (Fig. 2) and since lost 


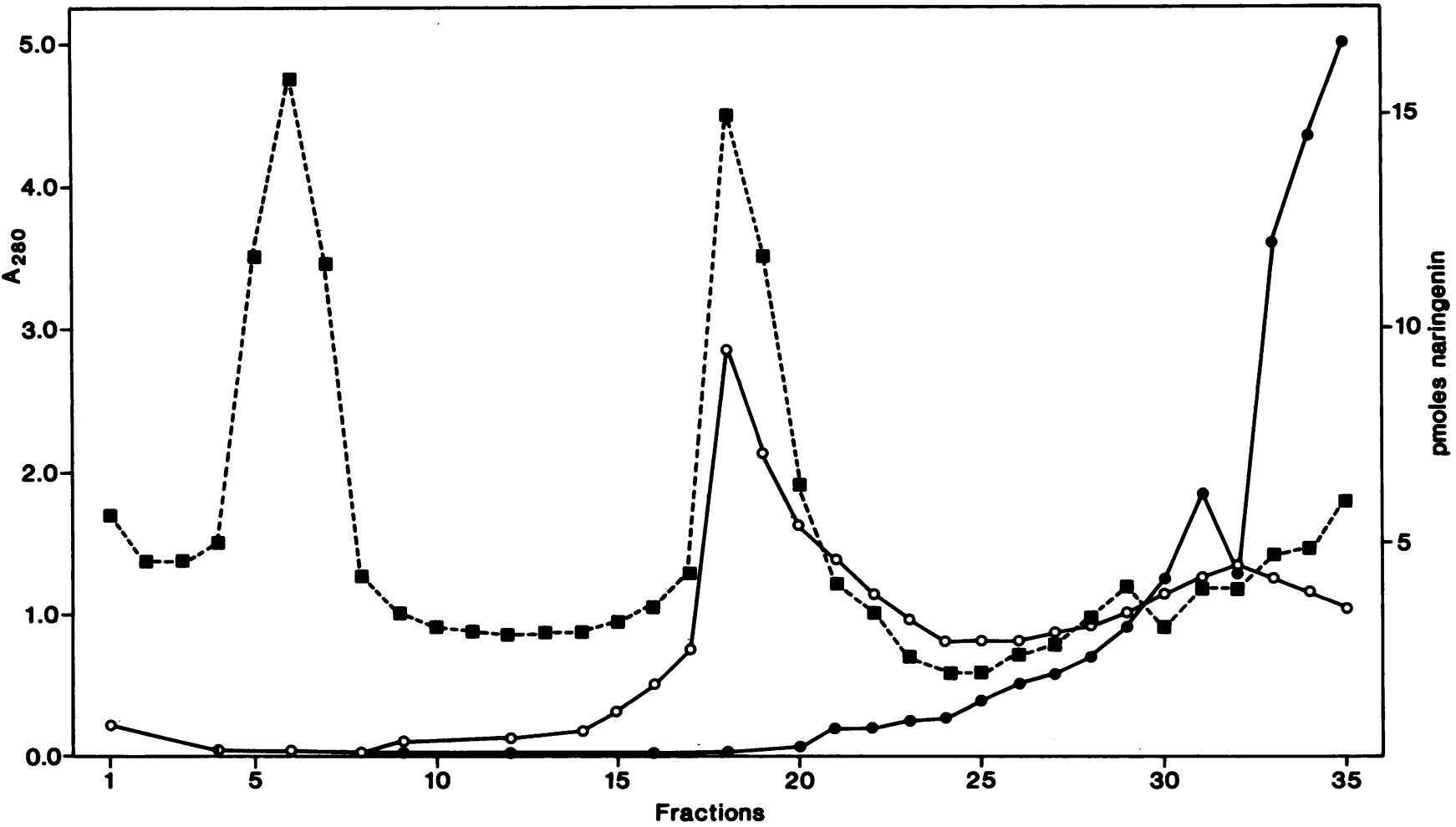

FIG. 5. Distribution of $\left[{ }^{3} \mathrm{H}\right]$ naringenin $(75 \mathrm{pmol})$ after isopycnic sucrose density centrifugation of total cell membranes of strain RBL5560 at $\mathrm{pH} 5.7(\bigcirc)$ and $\mathrm{pH} 9.7(\bullet)$. The two $A_{280}$ peaks $(\boldsymbol{\square})$ were identified as the outer (fractions 4 to 8 ) and cytoplasmic (fractions 17 to 21 ) membrane, respectively, as described in the text.

$\left[{ }^{3} \mathrm{H}\right]$ naringenin is unlikely to combine again with membrane vesicles during passage through the gradient, low-affinity binding to the outer membrane cannot be excluded. These data strongly suggest that naringenin accumulation by whole cells (Fig. 1) is not caused by nonspecific binding to the cell surface but by accumulation in the cytoplasmic membrane.

The partitioning of flavonoids between an olive oil phase and an aqueous phase has been shown to reflect its affinity for lipid bilayers (2). The observation that naringenin accumulates in the olive oil fraction of an olive oil-water biphasic system (Fig. 3) in a pH-dependent way similar to that by which it accumulates in whole cells (Fig. 3) and the cytoplasmic membrane (Fig. 5) indicates that the hydrophobic environment of the cytoplasmic membrane is sufficient to ensure accumulation. A specific naringenin-binding protein is not required to explain the data.

TABLE 2. Effect of $\mathrm{pH}$ on activation of nodAp

\begin{tabular}{lrc}
\hline & \multicolumn{2}{c}{$\begin{array}{c}\text { B-Galactosidase activity }(\mathrm{kU})^{a} \text { at } \\
\text { naringenin concn: }\end{array}$} \\
\cline { 2 - 3 } & $20 \mathrm{nM}$ & $500 \mathrm{nM}$ \\
\hline 5.75 & 7.2 & 20 \\
6.00 & 11.2 & 27.5 \\
6.25 & 10.4 & 30 \\
6.50 & 9.0 & 30 \\
6.75 & 7.6 & 30 \\
7.00 & 5.2 & 30 \\
\hline
\end{tabular}

" $\beta$-Galactosidase activity was determined with strain RBL5560)(pMP154 as described in the Materials and Methods section. Values represent averages of three experiments after subtraction of the levels obtained without added naringenin $(\max ., 400 \mathrm{U})$. Standard deviation $=5 \%$.
Changes in $\mathrm{pH}$ cause alterations in the UV spectrum of naringenin (Fig. 4), presumably because at high $\mathrm{pH}$ the ionizable hydroxyl groups at positions $\mathrm{C}-7$ and $\mathrm{C}-4^{\prime}$ of naringenin become negatively charged. A similar $\mathrm{pH}$-dependent binding has been reported for the structurally related flavonoid phloretin to human erythrocytes (15) and black lipid membranes (1). Uncharged phloretin is able to increase the permeability of lipid membranes for ions, and it has been proposed that it interacts with the phospholipid bilayer due to its bipolar properties (1).

The differences found for the apparent pK's of the $\mathrm{pH}$ dependent partitioning for naringenin in the olive oil-water and the Rhizobium cell-water phases ( $\mathrm{pH} 7.7$ and 7.0, respectively) are possibly due to the difference in systems used. In the cell-medium system (distribution ratio in Fig. 3), the amount of naringenin in the medium changes little when the $\mathrm{pH}$ is changed because the cellular volume is only 0.32 $\mu \mathrm{l} / \mathrm{ml}$ of medium. In the olive oil-water system (Fig. 3), the amount of naringenin in the water phase changes profoundly when the $\mathrm{pH}$ is changed because the oil-to-water ratio is $1: 1$.

As far as could be tested, the available evidence (Table 2) shows a good correlation between naringenin accumulation as measured in this study and nod gene activation. In this respect, there is homology with the effects of flavonoids on membrane-bound transport ATPase, where a direct correlation between the affinity of different flavonoids for olive oil-water (1:1 mixture), synaptosomal vesicles, and the membrane-bound ATPase could be detected (2). In the same context, we report a direct correlation between the affinity of different forms of one flavonoid (Fig. 4) for bacteria and olive oil (Fig. 3), the cytoplasmic membrane (Fig. 5), and nod gene activation (Table 2 ). 
Naringenin was not identified as one of the naturally occurring nod gene activators in Vicia sativa root exudate. However, the inducers which have been characterized are also flavanones (S. A. J. Zaat, J. Schripsema, C. A. Wijffelman, A. A. N. Van Brussel, and B. J. J. Lugtenberg, Plant Mol. Biol., in press). The presence of ionizable hydroxyl groups appears to be a common feature of nod gene inducers, which makes naringenin an ideal model compound for the uptake study performed.

From our data, the following picture emerges for naringenin uptake and activation of NodD protein. (i) Naringenin traverses the outer membrane quickly, since the final accumulation level is reached almost instantaneously (Fig. 1). Despite its hydrophobicity, its low molecular weight (272) presumably allows naringenin to pass the outer membrane through aqueous pores. (ii) The un-ionized form of naringenin accumulates in the cytoplasmic membrane, since this provides the suitable hydrophobic environment. Its remains puzzling why accumulation in the outer membrane was not observed. Apparently the asymmetric outer membrane, with fatty acids of lipopolysaccharides in the outer leaflet $(17,18)$, does not provide a suitable environment for naringenin. It can be speculated either that the phospholipid bilayer is required or that the packing of the fatty acyl chains in the outer membrane is too tight to allow insertion of naringenin. Alternatively, it should be noted that our data do not exclude a specific receptor in the cytoplasmic membrane. However, since our uptake data are easily explained by the phospholipid bilayer, this possibility seems very remote. (iii) Naringenin, probably in its unaltered form (Fig. 2, inset), activates NodD protein. Since the nodD gene product has been localized in the cytoplasmic membrane (H. R. M. Schlaman, H. P. Spaink, R. J. H. Okker, and B. J. J. Lugtenberg, J. Bacteriol., in press) and naringenin appears to accumulate in the cytoplasmic membrane (Fig. 5), activation of nodD by naringenin most likely occurs in this cell compartment.

\section{ACKNOWLEDGMENTS}

We thank Wil N. Konings for valuable discussions.

The investigations were partly supported by the Foundation for Fundamental Biological Research (BION), which is subsidized by the Netherlands Organization for the Advancement of Research (NWO).

\section{LITERATURE CITED}

1. Andersen, O. S., A. Finkelstein, I. Katz, and A. Cass. 1976 Effect of Phloretin on the permeability of thin lipid membranes. J. Gen. Physiol. 67:749-771.

2. Barzilai, A., and H. Rhahamimoff. 1983. Inhibition of $\mathrm{Ca}^{2+}$. transport ATP-ase from synaptosomal vesicles by flavonoids. Biochim. Biophys. Acta 730:245-254.

3. Burn, J., L. Rossen, and A. W. B. Johnston. 1987. Four classes of mutations in the nodD gene of Rhizobium leguminosarum biovar viciae that affect its ability to autoregulate and/or activate other nod genes in the presence of flavonoid inducers. Genes Dev. 1:456-464.

4. De Maagd, R. A., and B. J. J. Lugtenberg. 1986. Fractionation of Rhizobium leguminosarum cells into outer membrane, cytoplasmic membrane, and periplasmic and cytoplasmic components. J. Bacteriol. 167:1083-1085.

5. Firmin, J. L., K. E. Wilson, L. Rossen, and A. W. B. Johnston. 1986. Flavonoid activation of nodulation genes in Rhizobium reversed by other compounds present in plants. Nature (London) 324:90-92.

6. Fisher, R. F., T. T. Egelshoff, J. T. Mulligan, and S. R. Long. 1988. Specific binding of proteins from Rhizobium meliloti cell-free extracts containing NodD to DNA sequences upstream of inducible nodulation genes. Genes Dev. 2:282-293.

7. Havsteen, B. 1983. Flavonoids, a class of natural products of pharmacological potency. Biochem. Pharmacol. 32:1141-1148.

8. Hong, G. F., J. E. Burn, and A. W. B. Johnston. 1987. Evidence that DNA involved in the expression of nodulation (nod) genes in Rhizobium binds to the product of the regulatory gene nodD. Nucleic Acids Res. 15:9677-9690.

9. Honma, M. A., and F. M. Ausubel. 1987. Rhizobium meliloti has three copies of the nodD symbiotic regulatory gene. Proc. Natl. Acad. Sci. USA 84:8558-8562.

10. Hooykaas, P. J. J., A. A. N. van Brussel, H. Den Dulk-Ras, G. M. S. van Slogteren, and R. A. Schilperoort. 1981. Sym plasmid of Rhizobium trifolii expressed in different rhizobial species and Agrobacterium tumefaciens. Nature (London) 291: 351-353.

11. Horvath, B., C. W. B. Bachem, J. Schell, and A. Kondorosi. 1987. Host-specific regulation of nodulation genes in Rhizobium is mediated by a plant-signal interacting with the nodD gene product. EMBO J. 6:841-848.

12. Kashket, E. R. 1981. Proton motive force in growing Streptococcus lactis and Staphylococcus aureus cells under aerobic and anaerobic conditions. J. Bacteriol. 146:369-376.

13. Kondorosi, E., Z. Banfalvi, and A. Kondorosi. 1984. Physical and genetic analysis of a symbiotic region of Rhizobium meliloti: identification of nodulation genes. Mol. Gen. Genet. 193:445452.

14. Kosslak, R. M., R. Bookland, J. Barkei, H. E. Paaren, and E. R. Applebaum. 1987. Induction of Bradyrhizobium japonicum common nod genes by isoflavones isolated from Glycine max. Proc. Natl. Acad. Sci. USA 84:7428-7432.

15. LeFevre, P. G., and J. K. Marshall. 1959. The attachment of phloretin and analogues to human erythrocytes in connection with inhibition of sugar transport. J. Biol. Chem. 234:3022-3026.

16. Lowry, O. H., N. J. Rosebrough, A. L. Farr, and R. J. Randall. 1951. Protein measurement with the Folin phenol reagent. J. Biol. Chem. 193:265-275.

17. Lugtenberg, B., and L. van Alphen. 1983. Molecular architecture and functioning of the outer membrane of Escherichia coli and other gram-negative bacteria. Biochim. Biophys. Acta 737:51-115.

18. Nikaido, N., and M. Vaara. 1985. Molecular basis of bacterial outer membrane permeability. Microbiol. Rev. 49:1-32.

19. Peters, N. K., J. W. Frost, and S. R. Long. 1986. A plant flavone, luteolin, induces expression of Rhizobium meliloti nodulation genes. Science 233:977-980.

20. Redmond, J. W., M. Batley, M. A. Djordjevic, R. W. Innes, P. L. Kuempel, and B. G. Rolfe. 1986. Flavones induce expression of nodulation genes in Rhizobium. Nature (London) 323: $632-635$.

21. Smit, G., J. W. Kijne, and B. J. J. Lugtenberg. 1986. Correlation between extracellular fibril and attachment of Rhizobium leguminosarum to pea root hair tips. J. Bacteriol. 168:821-827.

22. Spaink, H. P., C. A. Wijffelman, E. Pees, R. J. H. Okker, and B. J. J. Lugtenberg. 1987. Rhizobium nodulation gene nodD as a determinant of host specificity. Nature (London) 328:337-340.

23. Van Batenburg, F. H. D., R. Jonker, and J. W. Kijne. 1986. Rhizobium induces marked root hair curling by redirection of tip growth: a computer simulation. Physiol. Plant. 66:476-480.

24. Van Brussel, A. A. N., S. A. J. Zaat, H. C. J. Canter Cremers, C. A. Wijffelman, E. Pees, T. Tak, and B. J. J. Lugtenberg. 1986. Role of plant root exudate and Sym plasmid-localized nodulation genes in the synthesis by Rhizobium leguminosarum of Tsr factor, which causes thick and short roots on common vetch. J. Bacteriol. 165:517-522.

25. Vincent, J. M. 1980 . Factors controlling the legume-Rhizobium symbiosis, p. 103-129 In W. E. Newton and W. H. OrmeJohnson (ed.), Nitrogen fixation, vol. 2. University Park Press, Baltimore

26. Wijffelman, C., B. Zaat, H. Spaink, I. Mulders, T. van Brussel, R. Okker, E. Pees, R. de Maagd, and B. Lugtenberg. 1986. Induction of Rhizobium nod genes by flavonoids: differential adaption of promotor, nodD gene and inducers for various 
cross-inoculation groups, p. 123-135. In B. Lugtenberg (ed.), Recognition in microbe-plant symbiotic and pathogenic interactions. Springer-Verlag, Heidelberg.

27. Zaat, S. A. J., C. A. Wijffelman, H. P. Spaink, A. A. N. van Brussel, R. J. H. Okker, and B. J. J. Lugtenberg. 1987. Induction of the nodA promoter of Rhizobium leguminosarum by plant flavanones and flavones. J. Bacteriol. 169:198-204.

28. Zaat, S. A. J., C. A. Wijffelman, I. H. M. Mulders, A. A. N. van Brussel, and B. J. J. Lugtenberg. 1988. Root exudates of various host plants of Rhizobium leguminosarum contain different sets of inducers of Rhizobium nodulation genes. Plant Physiol. 86:1298-1303. 